\title{
Effects of castration on specific glycoprotein secretions of the epididymis in the rabbit and hamster
}

\author{
H. D. M. Moore \\ Wellcome Laboratories of Comparative Physiology, Institute of Zoology, \\ Zoological Society of London, Regent's Park, London NW1 4RY, U.K.
}

\begin{abstract}
Summary. Mature male rabbits and hamsters were bilaterally castrated and their epididymides were examined, at 2, 4, 7, 9 and 14 days after operation, for the presence of several glycoproteins by using monospecific antisera and indirect immunoperoxidase labelling. In the rabbit, there was a reduction in the glycoprotein reaction product in the epithelium of the proximal caput epididymidis by 2-4 days after castration, and the staining was weak or absent by 7-9 days. Compared with controls, there was also a marked decrease in the intensity of reaction product to glycoprotein in the lumen of the proximal and distal corpus epididymidis 2-4 days after castration although spermatozoa still filled the duct in this region. Glycoprotein was present in the distal cauda epididymidis at 14 days but staining diminished as spermatozoa were cleared from the tract. In the hamster, epididymal glycoproteins were apparently less critically dependent on androgens than those in the rabbit, reaching a weak but constant level in the proximal region by 7-9 days after castration and remaining at the same intensity in the distal cauda epididymidis throughout the study.

These results suggest that the secretion of specific glycoproteins by the mammalian epididymis is related to androgen levels and to sperm maturation.
\end{abstract}

\section{Introduction}

The processes of the mammalian epididymis which confer on spermatozoa their fertilizing ability and survival are maintained by circulating androgens (see Orgebin-Crist, Danzo \& Davies, 1975). Hence in most laboratory animals, castration or hypophysectomy results in a rapid decline in the development of sperm fertility within 4-7 days, and the loss of sperm viability after 1-2 weeks (Orgebin-Crist, Davies \& Tichenor, 1973; Lubicz-Nawrocki \& Glover, 1973). However, the nature of the androgen-dependent activities of the epididymis essential for sperm maturation and storage is not known.

Changes in the fine structure of epididymal epithelium cells (principal cells) following androgen withdrawal, concomitant with the failure of sperm maturation, include a sudden decrease in rough endoplasmic reticulum and a disappearance of smooth and coated vesicles from the apical cell border (Orgebin-Crist \& Davies, 1974; Moore \& Bedford, 1979). These observations suggest that there is a rapid cessation of macromolecule production and secretion, a conclusion supported by evidence from long-term studies showing that protein synthesis, and other metabolic processes in the epididymis, are much reduced after castration but can be restored by androgen replacement therapy (Allen \& Slater, 1958; Martan, 1969; Hamilton, Jones \& Fawcett, 1969; Brooks, 1976). 
Specific protein components are secreted by the epididymis (Lavon, Volcani \& Danon, 1971; Killian \& Amann, 1973; Koskimies \& Kormano, 1975) and the protein composition of epididymal fluid is altered dramatically by castration (Jones \& Glover, 1973). However, the role played by epididymal proteins in the development of sperm fertilizing ability is not understood. Furthermore, in only a few instances is it known which proteins present in the epididymal lumen are maintained by androgens. There are some testosterone-dependent proteins synthesized in rat epididymides (Cameo \& Blaquier, 1976). The content of sialic acid in the hamster and rhesus monkey epididymis can also be manipulated by different hormone regimens (Bose, Prasad \& Moudgal, 1975; Arora, Dinakar \& Prasad, 1975), and as this compound is associated with protein, it may indicate that some glycoprotein synthesis is androgen-dependent. Several specific glycoproteins have been isolated from whole rat epididymis (Lea, Petrusz \& French, 1978) and from rabbit and hamster epididymal fluid (Moore, 1980). These proteins, secreted by the epididymal epithelial cells, bind to spermatozoa in the region of the duct where they first acquire fertilizing ability.

The significance of glycoproteins for sperm maturation is unclear but an important first step is to establish whether their synthesis and secretion depends on adequate levels of androgens. This was investigated in the present study with rabbits and hamsters.

\section{Materials and Methods}

\section{Castrations}

Adult New Zealand White male rabbits $(3.5 \mathrm{~kg})$ with semen containing a high concentration of spermatozoa with good motility were selected for castration. Each of the 10 bucks was bilaterally castrated according to the following procedure. Anaesthesia was induced with an intravenous injection of pentobarbitone sodium (Sagatal: May \& Baker) and the inguinal canals were exposed by a ventral midline incision. Each testis and epididymis was located through an incision in the tunica vaginalis and the epididymis was carefully isolated from the testis. A ligature was placed around the testicular artery and vein which were then severed to remove the testis. The epididymis was replaced in the scrotum, the incision closed and the rabbit injected i.m. with 200000 i.u. penicillin.

Ten adult male Syrian hamsters $(150 \mathrm{~g})$ were bilaterally castrated in a similar manner but through an abdominal incision. Care was taken to return each epididymis to a scrotal position. Control animals ( 2 rabbits, 2 hamsters) were sham-operated, the testis and epididymis being manipulated but returned intact to the scrotum. In 2 rabbits and 2 hamsters, plasma androgen levels were monitored, before and after castration, by radioimmunoassay utilizing a testosterone antiserum which had a $35 \cdot 3 \%$ cross-reaction with $5 \alpha$-dihydrotestosterone (Bonney, Dixson \& Fleming, 1980). The method was validated for hamster and rabbit plasma and the sensitivity of the assay was $0.02 \mathrm{ng} / \mathrm{ml}$. The intra-assay coefficient of variation was $4.4 \%$.

At 2, 4, 7, 9 and 14 days after castration, 2 rabbits and 2 hamsters were killed and their excurrent ducts removed. Each epididymis was dissected free of fat and cut at the mid-corpus region to give two pieces of tissue; one consisting of the initial segments, caput and proximal corpus segments and the other of the distal corpus, cauda and proximal vas deferens regions. The epididymal tissue was immediately snap-frozen in isopentane at $-160^{\circ} \mathrm{C}$ and stored in liquid nitrogen.

\section{Immunocytochemistry}

The isolation of specific glycoproteins from rabbit and hamster epididymal fluid and the preparation of monospecific antisera to these proteins is described in detail elsewhere (Moore, 1980). Therefore only a brief description will be given here of the same glycoproteins under investigation in the present study. 
In all, 3 rabbit glycoproteins were investigated. These proteins, designated R1, R2 and R3, have isoelectric points of pI $3 \cdot 45,4 \cdot 15$, and $4 \cdot 65$, respectively, and are secreted by epididymal epithelial cells mainly in the caput and corpus epididymidis. They first bind to spermatozoa in the distal caput and proximal corpus region. Two hamster glycoproteins, $\mathrm{H} 1$ and $\mathrm{H} 2$, were also studied. Both of these proteins are secreted by the epididymal epithelium but only $\mathrm{H} 1$ is associated with spermatozoa (Moore, 1980).

To visualize the site of specific glycoproteins within the epididymis, the unlabelled antibody enzyme method of Sternberger (1973) was used. Monospecific antisera to rabbit and hamster glycoproteins were raised in either guinea-pigs (rabbit antigen) or rabbits (hamster antigen) as described previously (Moore, 1980). The purity of the antisera was investigated by immunoisoelectric focussing. Strips of polyacrylamide gel containing separated epididymal protein bands were overlayered on $1 \%$ agarose gel containing a particular antiserum and electrophoresis was performed for $16 \mathrm{~h}$. Each antiserum gave one precipitin peak corresponding to the isolated glycoprotein. Peroxidase-antiperoxidase was prepared by injecting guinea-pigs with horseradish peroxidase $(\mathrm{RZ}=3 \cdot 0$ : Sigma) or was obtained commercially (Miles-Yeda). Longitudinal sections (12 $\mathrm{m}$ thickness) of epididymal tissue from sham-operated controls and castrated animals were cut on a cryostat, air-dried and fixed in $10 \%$ formalin in $80 \%$ alcohol. To eliminate non-specific binding of anti-IgG, tissue sections were preincubated for 2 min in $10 \%$ pre-immune serum from the same animals in phosphate-buffered saline, $\mathrm{pH} 7.4$, and blotted on filter paper. The sections were then incubated for $10 \mathrm{~min}$ with glycoprotein antiserum (diluted $1: 50$ ), $10 \mathrm{~min}$ with anti-IgG antiserum (diluted $1: 5.0$ ) and $10 \mathrm{~min}$ with peroxidase-antiperoxidase (diluted 1:10). After each incubation the tissue was washed for 2 min with phosphate-buffered saline, $\mathrm{pH}$ 7.4. All appropriate controls were performed, including the omission of antiserum and its substitution with pre-immune serum. Visualization of the peroxidase-antiperoxidase marker was achieved by using $0.05 \%$ diaminobenzidine in $0.05 \mathrm{M}$-Tris- $\mathrm{HCl}$ buffer, $\mathrm{pH} 7.6$, containing $0.002 \%$ hydrogen peroxide.

\section{Results}

\section{Rabbit}

In the sham-operated controls, the localization of the glycoproteins was identical to that found in intact males. Since this has already been described in detail (Moore, 1980) only a summary will be given here. The rabbit epididymis was divided into regions as indicated in Text-fig. 1.

All 3 antigens were absent from the testis, efferent ducts and initial segments (regions 1 and 2) and were visualized first in the proximal caput epididymidis (region 3, Pl. 1, Fig. 1). The stain to glycoprotein in this region was confined to the cytoplasm of epithelial cells and their adluminal border as shown in Pl. 1, Fig. 2. In each case glycoprotein appeared to bind to spermatozoa initially in the distal caput and proximal corpus region (regions 4 and 5) as indicated by the increase of reaction product within the lumen there (Pl. 1, Fig. 3). Spermatozoa then remained

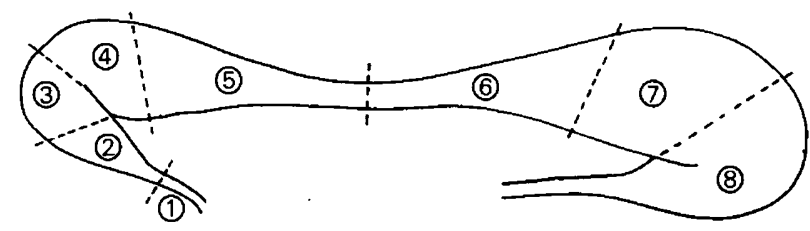

Text-fig. 1. Diagram of the rabbit epididymis to identify the various regions considered: (1) efferent ducts; (2) initial segments; (3) proximal caput; (4) distal caput; (5) proximal corpus; (6) distal corpus; (7) proximal cauda; (8) distal cauda and vas deferens. 
coated with protein throughout their passage through the excurrent duct although secretion of glycoprotein by epithelial cells diminished or failed completely in the distal corpus and cauda epididymidis (Pl. 1, Fig. 4).

The main differences in the response of the various glycoprotein fractions to castration are summarized in Table 1. The reduction in the amount of glycoprotein was first apparent in the proximal epididymis 2 days after castration for fractions $\mathrm{R} 1$ and $\mathrm{R} 3$ and after 4 days for protein

\section{PLATE 1}

Fig. 1. Frozen section of the proximal caput region of the epididymis of a sham-operated control rabbit showing the epithelium and spermatozoa present in the lumen. Haematoxylin, $\times 134$.

Fig. 2. A similar section to Fig. 1 after immunological staining for $R 1$ glycoprotein showing the reaction localized within the epididymal epithelium and at the adluminal border. The initial segment did not stain for specific glycoprotein. $\times 134$.

Fig. 3. Frozen section of the distal caput region (4) of a control rabbit. The immunocytochemical stain for glycoprotein R1 shows heavy staining of the luminal content. A similar pattern is seen in the proximal corpus. $\times 192$.

Fig. 4. Frozen section of a control rabbit epididymis in the distal cauda region stained for $\mathrm{R} 1$ glycoprotein. Reaction product is localized both on spermatozoa and at the epithelial adluminal border. $\times 115$.

Fig. 5. Frozen section of rabbit epididymis in the proximal caput region 2 days after castration showing the lumen devoid of spermatozoa. Haematoxylin, $\times 134$.

Fig. 6. A similar section to Fig. 5 but immunocytochemically stained for R 1 glycoprotein. Reaction product is still present at the adluminal border of the epithelium but the intensity of stain within principal cells has diminished after castration (compare with Fig. 2). $\times 134$.

\section{PLATE 2}

Fig. 7. Frozen section of rabbit proximal caput epididymidis 9 days after castration. The lumen has contracted in the absence of any content and the height of the epithelium has diminished. Haematoxylin, $\times 134$.

Fig. 8. A similar section to Fig. 7 but stained for R1 glycoprotein. Reaction product is absent from the section indicating a lack of glycoprotein antigen. The same results were obtained with glycoproteins R2 and R3. $\times 134$.

Figs 9 and 10. Frozen sections from the distal corpus epididymidis of a control rabbit (Fig. 9) and of a 4-day castrate (Fig. 10), stained for R1 glycoprotein. Although spermatozoa are still present in the distal corpus region 4 days after castration, the luminal content is not stained with the same intensity as that of controls even after prolonged incubation of the section. Note the reduction in the height of the epithelium. $\times 115$.

Fig. 11. Frozen section of the rabbit distal cauda epididymidis 14 days after castration. At this stage the luminal contents are absent from the more distal regions of the duct. Haematoxylin, $\times 105$.

Fig. 12. A similar section to Fig. 11 stained for $R 2$ glycoprotein shows a small amount of reaction product present at the adluminal border of the epithelium, indicating the presence of antigen. $\times 105$.

Fig. 13. Frozen section of the distal caput epididymidis (region 4) of a control hamster stained for $\mathrm{H} 1$ glycoprotein. Dense reaction product is localized mainly in the lumen but is also associated with epithelial cells. $\times 134$.

Fig. 14. A frozen section of the distal corpus epididymidis of a hamster 14 days after castration, stained immunocytochemically for $\mathrm{H} 1$ antigen. Although the width of the tubules has diminished, reaction product is still present in the epididymal lumen. $\times 115$.

Fig. 15. A frozen section of the proximal caput epididymidis of a hamster 7 days after castration, stained for $\mathrm{H} 1$ glycoprotein. In the absence of spermatozoa within the lumen, reaction product is confined to the adluminal border of the epithelium. $\times 115$. 
PLATE 1
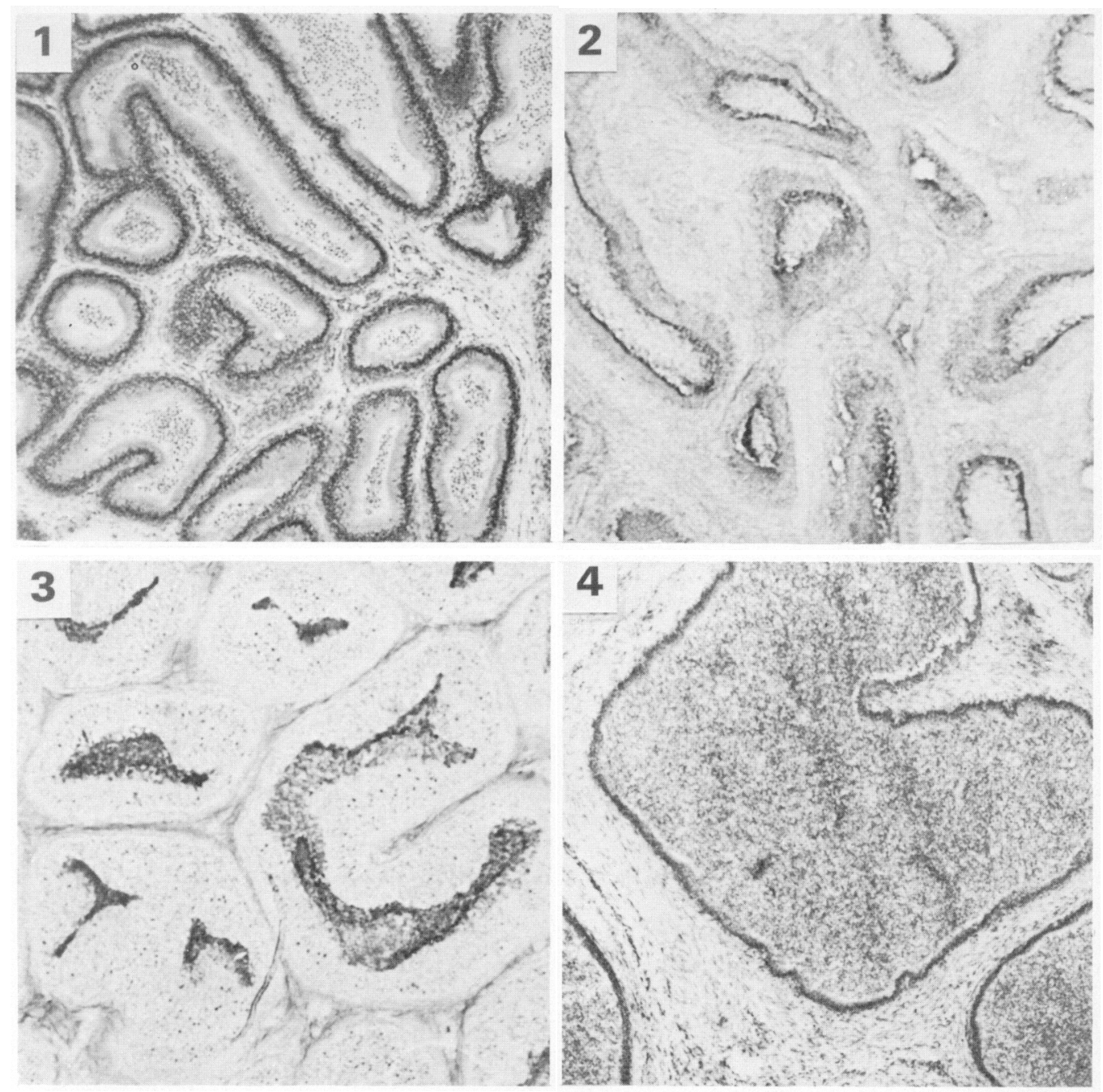

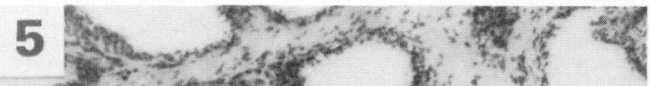

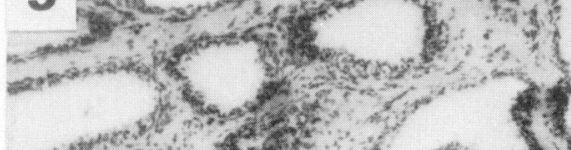

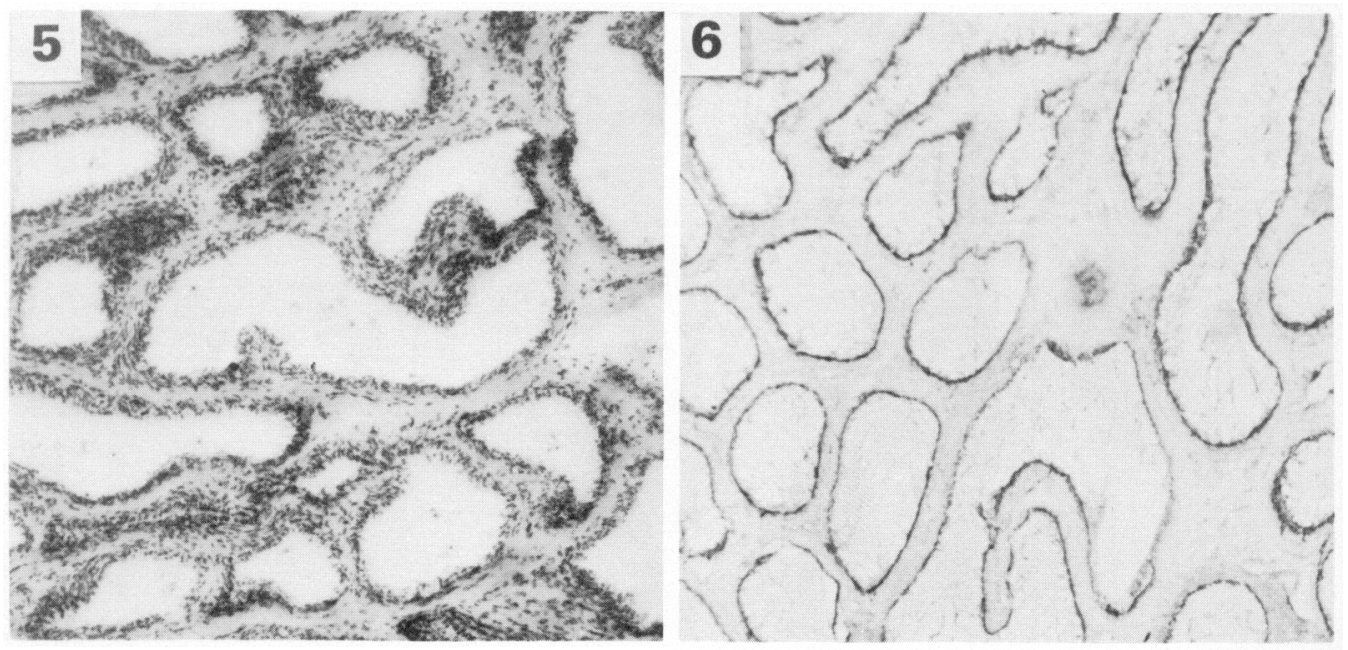

(Facing p. 350) 
PLATE 2
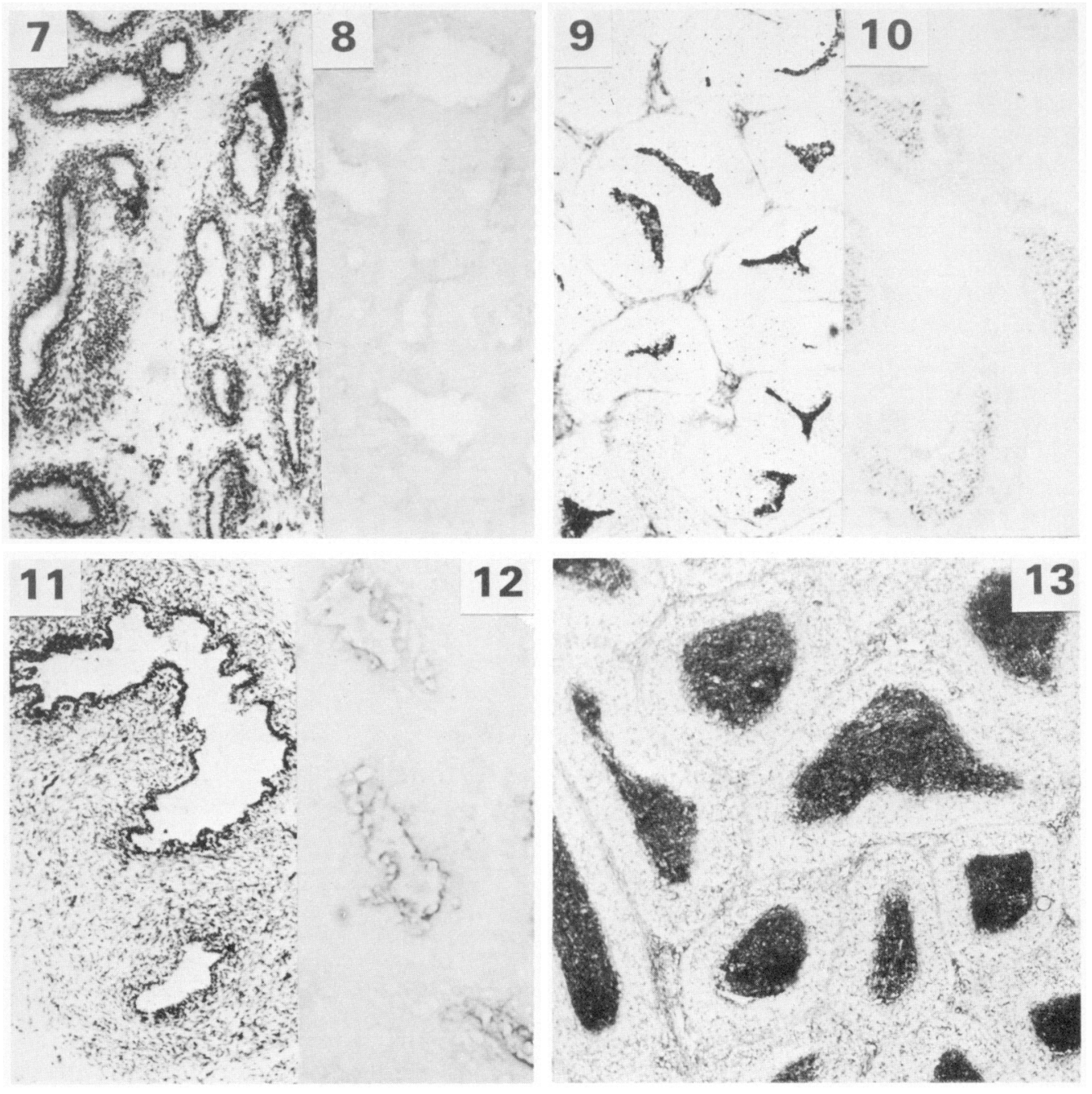

\section{1) 6}

- 9 की
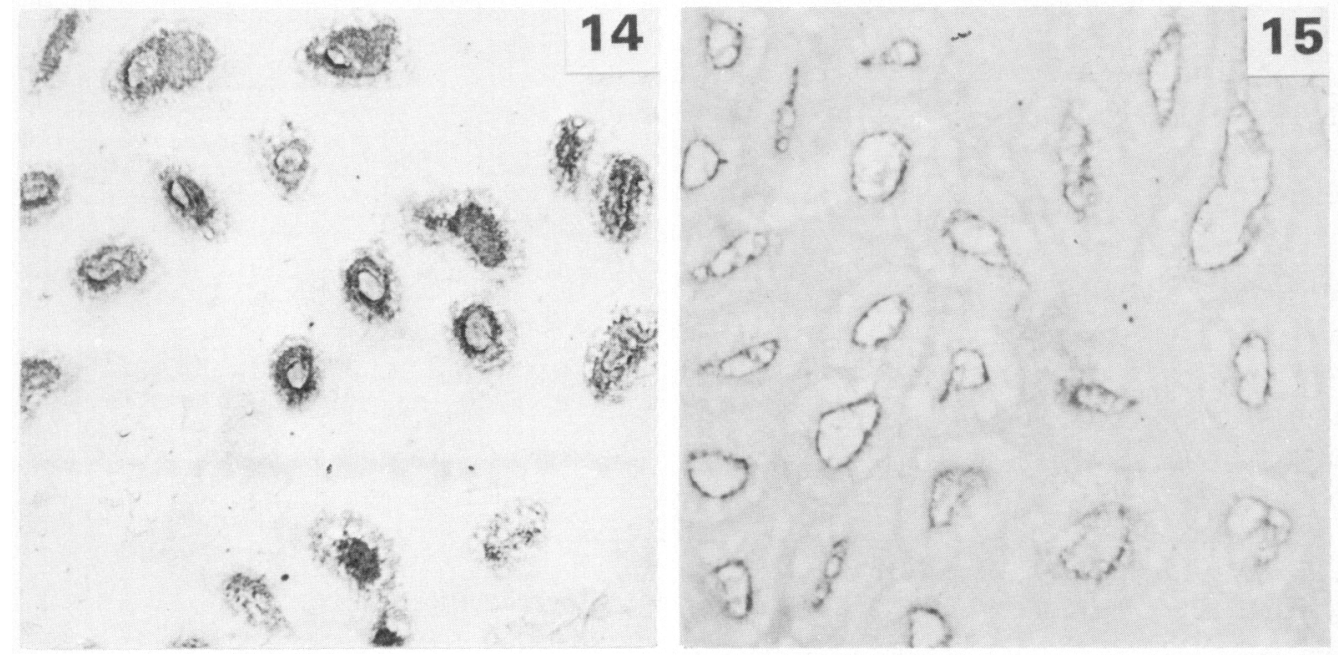
R2. In the proximal caput (region 3; Pl. 1, Fig. 5) the decline in the concentration of all 3 glycoproteins was characterized initially by a less intense staining of epithelial cells, although the amount of reaction product at the adluminal border seemed at first to remain constant (Pl. 1, Fig. 6). As the proximal epididymal lumen contracted in the absence of any content, however, staining to glycoprotein was further diminished and by 7-9 days after castration was very weak or could not be obtained (Pl. 2, Figs 7 and 8). A similar pattern in the decline of reaction product to glycoprotein was observed in epithelial cells of the distal caput and proximal corpus epididymidis, although spermatozoa were still present in the lumen 4 days after castration. Despite the presence of spermatozoa, the intensity of the stain in the lumen of the proximal corpus region diminished markedly 2-4 days after castration compared with that of the luminal contents in the distal cauda epididymidis or of the corpus region of control animals (Pl. 2, Figs 9 and 10). Glycoproteins in the distal cauda epididymidis were visualized in the duct lumen up to 14 days after castration but staining waned in the proximal cauda region as spermatozoa were cleared from the tract (Pl. 2, Figs 11 and 12).

Table 1. Changes in the staining intensity to various glycoprotein fractions in the epididymis of the rabbit and hamster after castration

\begin{tabular}{|c|c|c|c|c|c|c|}
\hline \multirow[b]{2}{*}{ Glycoprotein fraction } & \multirow{2}{*}{$\begin{array}{l}\text { Region of } \\
\text { epididymis* }\end{array}$} & \multicolumn{5}{|c|}{$\begin{array}{l}\text { Maximum intensity } \dagger \text { of glycoprotein reaction product } \\
\text { in the epididymal lumen after castration }\end{array}$} \\
\hline & & 2 days & 4 days & 7 days & 9 days & 14 days \\
\hline Rabbit R 1 & $\begin{array}{l}\text { Caput } 4 \\
\text { Cauda } 8\end{array}$ & $\begin{array}{r}++ \\
+++\end{array}$ & $\begin{array}{r}+ \\
++\end{array}$ & + & + & + \\
\hline Rabbit R2 & $\begin{array}{l}\text { Caput } 4 \\
\text { Cauda } 8\end{array}$ & $\begin{array}{l}+++ \\
+++\end{array}$ & $\begin{array}{r}++ \\
+++\end{array}$ & $\begin{array}{l}(+) \\
++\end{array}$ & + & $(+)$ \\
\hline Rabbit R3 & $\begin{array}{l}\text { Caput } 4 \\
\text { Cauda } 8\end{array}$ & $\begin{array}{r}++ \\
+++\end{array}$ & $\begin{array}{r}+ \\
++\end{array}$ & $\begin{array}{l}(+) \\
++\end{array}$ & + & + \\
\hline Hamster H1 & $\begin{array}{l}\text { Caput } 4 \\
\text { Cauda } 8\end{array}$ & $\begin{array}{l}+++ \\
+++\end{array}$ & $\begin{array}{r}++ \\
+++\end{array}$ & $\begin{array}{r}++ \\
+++\end{array}$ & $\begin{array}{l}(+) \\
++\end{array}$ & $\begin{array}{l}(+) \\
++\end{array}$ \\
\hline Hamster $\mathrm{H} 2$ & $\begin{array}{l}\text { Caput } 4 \\
\text { Cauda } 8\end{array}$ & $\begin{array}{r}+++ \\
++\end{array}$ & $\begin{array}{r}+++ \\
++\end{array}$ & $\begin{array}{r}+++ \\
++\end{array}$ & $\begin{array}{l}++ \\
++\end{array}$ & $\begin{array}{l}++ \\
++\end{array}$ \\
\hline
\end{tabular}

* See Text-fig. 1 .

++++ , Heavy; ++ , medium; + , light; - , absent. Values in parentheses indicate maximum staining at the adluminal border of the epithelium.

In the 2 rabbits in which plasma testosterone concentrations were monitored, castration resulted in an immediate decline of androgens to $6-8 \%(0.12 \mathrm{ng} / \mathrm{ml})$ of pre-castration values after 1 day and to $2-4 \%(0.65 \mathrm{ng} / \mathrm{ml})$ after 10 days.

\section{Hamster}

Localization of the glycoprotein fractions $\mathrm{H} 1$ and $\mathrm{H} 2$ in control animals was the same as that reported previously for intact males (Moore, 1980). Glycoprotein H1 was present in epithelial cells in the caput and corpus epididymidis (excluding the initial segment and up to the proximal cauda region) and was associated with spermatozoa in all regions of the duct, except in the initial segment (Pl. 2, Fig. 13). By contrast, fraction $\mathrm{H} 2$ was limited to epithelial cells in mainly the caput epididymidis and to the adluminal border of the epithelium and apparently did not bind to spermatozoa.

Glycoproteins in the hamster epididymis appeared to be less critically dependent on androgens than were those studied in the rabbit. For example, glycoprotein $\mathrm{H} 1$ was still detectable in the distal corpus epididymidis 14 days after castration even though reaction product was limited to the much reduced lumen (Pl. 2, Fig. 14). In the proximal region of the duct, the amount of $\mathrm{H} 1$ and $\mathrm{H} 2$ antigen decreased rapidly, as indicated by a general reduction in reaction 
product at 2-4 days after castration, but by about 7-9 days a nadir was reached after which the staining intensity remained weak, but constant (Pl. 2. Fig. 15). The glycoprotein fractions in the distal cauda epididymidis appeared similar throughout the study with spermatozoa being stained with $\mathrm{H} 1$ antigen with equal intensity at all times.

Plasma androgen concentrations fell rapidly in the hamster after castration with the levels reduced to $3-7 \%(0.08 \mathrm{ng} / \mathrm{ml})$ of pre-castration values after 1 day and being undetectable after 10 days.

\section{Discussion}

For an epididymal secretion to be considered as a factor influencing sperm maturation it must be secreted proximal to, or in the region of the epididymis where spermatozoa first become fertile, and it will probably be maintained by androgens (Orgebin-Crist et al., 1975). Specific glycoproteins of the rabbit and hamster epididymis fulfil the first criterion since they are secreted mainly in the distal caput and proximal corpus regions of the epididymis in the rabbit and throughout the proximal epididymis (excepting the initial segment) in the hamster (Moore, 1980). This present investigation has now established that their synthesis declines rapidly after castration when androgen levels are low.

In the epithelium of the rabbit caput epididymidis, the intensity of the reaction product to all 3 glycoprotein antigens had decreased appreciably within 2-4 days compared with that in control animals. Separate precipitin peaks on immunoisoelectric focussing indicated that these glycoproteins were immunologically distinct. Since the immunocytochemical procedures were kept constant, this reduction almost certainly represented a fall in the amount of the antigens present in the tissue. In addition, and perhaps of more significance, spermatozoa in the initial segment and proximal caput at the time of castration (i.e. the last spermatozoa passing through the epididymis after castration) were never stained to the same degree as those in the more distal region, suggesting that less antigen bound to these cells. In the time it takes for these spermatozoa to reach the distal corpus (4-7 days after castration), the spermatozoa recovered from this region are completely unable to fertilize (Orgebin-Crist et al., 1973). In contrast, spermatozoa in the more distal regions of the epididymis at the time of castration remain stained to the same extent at all times after androgen withdrawal (i.e. up to 14 days after castration). This is consistent with the fact that spermatozoa from the distal epididymis remain fertile for at least 1 week after castration and for more than 2 weeks after hypophysectomy (Orgebin-Crist et al., 1975). However, it is possible that the sperm storage functions of the mammalian epididymis are maintained by mechanisms different from those involved in sperm maturation (see Hamilton, 1975).

Although hamster spermatozoa seem more critically dependent on a functional epididymis for their maturation than are spermatozoa of other laboratory species (Lubicz-Nawrocki \& Glover, 1973), glycoprotein antigens apparently remained in the epididymal tissue for a longer period after castration than in the rabbit. Fraction $\mathrm{H} 2$ did not bind to spermatozoa, perhaps because it is not involved in the maturation of the sperm surface, but the $\mathrm{H} 1$ protein was secreted in large concentrations in the proximal regions of the epididymis of intact animals and bound to spermatozoa there. Its concentration declined markedly following castration, but residual antigen could still be detected up to the end of the study period in the lumen of the distal corpus region where spermatozoa first become fertile. This is still consistent with the idea that such a protein is necessary for maturation, since hamster spermatozoa may have a much higher requirement for glycoprotein than spermatozoa of the rabbit. Indeed, the differences in the mean net charge of spermatozoa from the caput and cauda epididymidis are much larger in the hamster than in the rabbit (Moore, 1979) and this observation is reflected in the greater number of lectin binding sites on hamster spermatozoa (Millette, 1977). In the rat, the concentration of specific epididymal 
proteins has been shown to decrease after castration in a manner similar to that observed in the hamster (Kohane, Garberi, Cameo \& Blaquier, 1979). A rapid initial decrease after 2 days was followed by a slower decrease and $38 \%$ of the proteins were still present after 14 days.

At present it has not been ascertained what exact role epididymal specific glycoproteins might play during sperm maturation but there are indications that they may be involved in modifying the sperm surface. Several studies have shown that the changes in the surface character of spermatozoa during epididymal passage are due, in part, to alterations in the carbohydrate moieties on the plasmalemma (Edelman \& Millette, 1971; Nicolson, 1974; Temple-Smith \& Bedford, 1976; Bedford \& Millar, 1978), some of which may result from the acquisition of glycoproteins (Fléchon, 1975; Olson \& Hamilton, 1978). Whether these particular sperm surface components are of epididymal origin has not been verified, although in the present study most of the glycoprotein fractions were in close association with spermatozoa in the region of the epididymis where changes in the sperm membrane are known to occur (see Bedford, 1975).

I thank Mr Trevor Hartman for technical assistance and Mr Terry Dennett for photography. This study was supported by a grant from the Ford Foundation.

\section{References}

Allen, J.M. \& Slater, J.J. (1958) A chemical and histochemical study of acid phosphatase in the epididymis of normal, castrate and hormone replaced castrated mice. Anat. Rec. 130, 731-745.

Arora, R., Dinakar, N. \& Prasad, M.R.N. (1975) Biochemical changes in the spermatozoa and luminal contents of different regions of the epididymis of the rhesus monkey, Macaca mulatta. Contraception 11, 689-699.

Bedford, J.M. (1975) Maturation, transport and fate of spermatozoa in the epididymis. In Handbook of Physiology, Male Reproductive Systems., Section 7, Vol. V, pp. 303-317. Eds R. O. Greep \& E. B. Astwood, Am. Physiol. Soc., Washington, D.C.

Bedford, J.M. \& Millar, R.P. (1978) The character of sperm maturation in the epididymis of the ascrotal hyrax, Procavia capensis and armadillo, Dasypus novemcinctus. Biol. Reprod. 19, 396-406.

Bonney, R.C., Dixson, A.F. \& Fleming, D. (1980) Plasma concentrations of oestradiol-17ß, oestrone, progesterone and testosterone during the ovarian cycle of the owl monkey (Aotus trivirgatus). $J$. Reprod. Fert. 60, 101-107.

Bose, T.K., Prasad, M.R.N. \& Moudgal, N.R. (1975) Changing patterns of sialic acid in spermatozoa and luminal plasma of the epididymis and vas deferens of the hamster, Mesocricetus auratus. Indian J. exp. Biol. 13, 9-12.

Brooks, D.E. (1976) Activity and androgenic control of glycolytic enzymes in the epididymis and epididymal spermatozoa of the rat. Biochem. J. 156, 527-537.

Cameo, M.S. \& Blaquier, J.A. (1976) Androgencontrolled specific proteins in rat epididymis. $J$. Endocr. 69, 47-55.

Edelman, G.N. \& Millette, C.F. (1971) Molecular probes of spermatozoon structures. Proc. natn. Acad. Sci. U.S.A. 68, 2436-2440.
Fléchon, J.E. (1975) Ultrastructural and cytochemical modifications of rabbit spermatozoa during epididymal transport. In Biology of Spermatozoa, pp. 35-45. Eds E. S. E. Hafez \& C. G. Thibault. Karger, Basel.

Hamilton, D.W. (1975) Structure and function of the epithelium lining the ductuli efferentes, ductus epididymides and ductus deferens in the rat. In Handbook of Endocrinology, Male Reproductive Systems, section 7, Vol. V, pp. 259-302. Eds R. O. Greep \& E. B. Astwood. Am. Physiol. Soc., Washington. D.C.

Hamilton, D.W., Jones, A.L. \& Fawcett, D.W. (1969) Cholesterol biosynthesis in the mouse epididymis and ductus deferens: a biochemical and morphological study. Biol. Reprod. 1, 167-184.

Jones, R. \& Glover, T.D. (1973) The effects of castration on the composition of rabbit epididymal plasma. $J$. Reprod. Fert. 34, 405-414.

Killian, G.J. \& Amann, R.P. (1973) Immunoelectrophoretic characterization of fluid and sperm entering and leaving the bovine epididymis. Biol. Reprod. 9 , 489-499.

Kohane, A.C., Garberi, J.C., Cameo, M.S. \& Blaquier, J.A. (1979) Quantitative determination of specific proteins in rat epididymis. J. Steroid Biochem. 11, 671-674.

Koskimies, A.I. \& Kormano, M. (1975) Proteins in fluids from different segments of the rat epididymis. $J$. Reprod. Fert. 43, 345-348.

Lavon, U., Volcani, R. \& Danon, D. (1971) The proteins of bovine spermatozoa from the caput and cauda epididymis. J. Reprod. Fert. 24, 210-232.

Lea, O.A., Petrusz, P. \& French, F.S. (1978) Purification and localization of acidic epididymal glycoprotein (AEG): A sperm coating protein secreted by the rat epididymis. Int. J. Androl., Suppl. 2, 592-605. 
Lubicz-Nawrocki, C.M. \& Glover, T.D. (1973) The influence of the testis on the survival of spermatozoa in the epididymis of the golden hamster, Mesocricetus auratus. J. Reprod. Fert. 34, 315-329.

Martan, J. (1969) Epididymal histochemistry and physiology. Biol. Reprod., Suppl. 1, 315-329.

Millette, C.F. (1977) Distribution and mobility of lectin binding sites on mammalian spermatozoa. In Immunobiology of Gametes, pp. 51-71. Eds M. Edidin \& M. H. Johnson. Cambridge University Press.

Moore, H.D.M. (1979) The net surface charge of mammalian spermatozoa as determined by isoelectric focussing. Changes following sperm maturation, ejaculation, incubation in the female tract and after enzyme treatment. Int. J. Androl. 2, 449-462.

Moore, H.D.M. (1980) Localisation of specific glycoproteins secreted by the rabbit and hamster epididymis. Biol. Reprod. 22, 705-718.

Moore, H.D.M. \& Bedford, J.M. (1979) Short-term effects of androgen withdrawal on the structure of different epithelial cells in the rat epididymis. Anat. Rec. 193, 293-312.

Nicolson, G.L. (1974) The interaction of lectins with animal cell surfaces. Int. Rev. Cytol. 39, 89-190.

Olson, G.E. \& Hamilton, D.W. (1978) Characterization of the surface glycoproteins of rat spermatozoa. Biol. Reprod. 19, 26-35.

Orgebin-Crist, M.-C. \& Davies, J. (1974) Functional and morphological effects of hypophysectomy and androgen replacement in the rabbit epididymis. Cell Tiss. Res. 148, 183-201.

Orgebin-Crist, M.-C., Davies, J. \& Tichenor, P. (1973) Maturation of spermatozoa in the rabbit epididymis: effect of hypophysectomy and castration. In The Regulation of Mammalian Reproduction, pp. 189203. Eds S. J. Segal, R. Crozier, P. A. Corfman \& P. G. Condliffe. Thomas, Springfield.

Orgebin-Crist, M.-C. Danzo, B.J. \& Davies, J. (1975) Endocrine control of the development and maintenance of sperm fertilizing ability in the epididymis. In Handbook of Endocrinology, Male Reproductive Systems, Section 7, Vol. V, pp. 319-338. Eds R. O. Greep \& E. B. Astwood. Am. Physiol. Soc., Washington D.C.

Sternberger, L.A. (1973) Enzyme immunocytochemistry. In Electron Microscopy of Enzymes, Vol. 1, Principles and Methods, pp. 150-191. Ed. M. A. Hayat. Van Nostrand Reinhold, New York.

Temple-Smith, P.D. \& Bedford, J.M. (1976) The features of sperm maturation in the epididymis of a marsupial, the Brush-tailed possum, Trichosurus vulpecula. Am. J. Anat. 147, 471-500.

Received 6 May 1980 